\title{
10 Conclusions
}

\section{1 "Shallow" Syncretism}

Based on my research I argue that the mutual influence of Islam and Christianity in the Western Rhodopes (with the exception of the kurban or blood sacrifice) does not involve 'deep' syncretism. 'Shallow' syncretism is the dominant form, making the emergence of a new form of Muslim-Christian or Christian-Muslim religion unlikely.

By examining personal, first-hand interpretations behind the apparently syncretic religious gestures, religious syncretism is revealed as an ambiguous phenomenon masking contradictory feelings about the other group and its religion. In practical terms, most of the apparently syncretic gestures are engaged in mimetically for a variety of motives. For instance, traditional festive foods may be offered to neighbours in the other religious group as a sign of friendship or fear of non-coreligionists, seen a potentially unpredictable group. Similarly, the research demonstrates that practices such as visiting the other religion's holy sites or healers (mostly treated by researchers as an evident symptom of religious syncretism and, in the case of the Pomaks, also as evidence of their crypto-Christianity) can only be described as superficially syncretic. Motivated by fear or a semi-conscious fascination with the alien sphere of the sacred, such syncretism has nothing to do with treating the other religion as an alternative way to salvation.

In the case of Bulgarian-speaking Muslims, 'shallow' religious syncretism is a cultural strategy calculated to maintain an anti-syncretic attitude by protecting religious boundaries from infiltration. The local Muslims regard Christianity with profound reserve, and their religious elites are openly looking to shake off the label of "crypto-Christians". Among other factors, this attitude stems from a fear of the assimilationist policies repeatedly experienced by the local Muslim population since 1912. The past experience of symbolic and physical violence (including compulsory baptism) is treated as a warning symbolizing an enduring threat to Muslim religious identity. As a result, Muslim religious elites seek to dissociate themselves not only from Christianity but also from their Bulgarian ethnic roots. Relatively knowledgeable about Christianity, they use this knowledge to discredit the religion and to deny its promises of salvation. For the elites, Christianity is a religion based on a misinterpretation of Jesus's original message, corrupted in the writings of the four evangelists and the apostle Paul: a religion of false revelations and empty rituals. These ideas are expressed differently by different sub-groups: the older (retirement-age) respondents representing the model of "Adat Islam" and the younger representatives of "Salafi Islam".

Proponents of "Adat Islam" rely on sacred narratives providing etiological interpretations of the errors of Christianity (for instance, the sign of the cross is presented as a misinterpretation of a gesture made by Jesus or the prophet 'Isa

(cc))BY-NC-ND $(C) 2015$ Magdalena Lubanska

This work is licensed under the Creative Commons Attribution-NonCommercial-NoDerivs 3.0 License. 
before ascending to heaven). Christianity is seen as a religion based on breaking the promise, made by the souls in paradise, to live in accordance with the requirements of Islam. At the same time, "Adat Islam" remains open to the possibility that some Christians might be saved. This openness is formulated in narratives such as the story of the camels which move good deceased Christians to Muslim graves, and bad Muslims to Christian graves. This model of Islam is perceptibly influenced by the religious culture of the Ottoman Empire, expressed in beliefs which betray strong parallels with the lives of the prophets popular in the Ottoman Empire, a problem identified and studied by Florentina Badalanova Geller (2008a, 2008b) and Galina Lozanova (2008). We know that in the first quarter of the 14th century the lives of the prophets were compiled by al-Rabghuzi (a judge from Western Turkmenistan) to form a collection which became very popular in the Ottoman Empire. Al-Rabghuzi based his work on the famous collection by al-Tabari, The History of the Prophets and Kings and the lives of the prophets by al-Tha'labi. My research had also yielded some interesting parallels to the source material collected by Frederick William Hasluck (1929), potentially indicating continued influence of the Ottoman model of Islam in the Western Rhodopes which, though waning, is still noticeable.

It should be emphasized that proponents of "Adat Islam" are mostly older representatives of the religious elite. Proponents of Salafi Islam clearly predominates among the younger members of the religious elite. Those are primarily hodzhas aged 30-40, many of them neophytes, some of them trained abroad, often in Arabic countries. This elite has a negative attitude not only to Christianity but also to "Adat Islam", which it associates with alien Ottoman and local Christian additions corrupting the original purity of Sunni Islam. This part of the elite treats "Adat Islam" as syncretic and "adulterated" by alien ideas and influences; its criticism of "Adat Islam" is vehement and sweeping, often mistakenly classifying orthodox beliefs as being incompatible with Sunni Islam. Such overzealous censure stems from lack of experience; in many cases, members of the religious elite had found an interest in Islam only several years previously, they are only familiar with the Qur'an and the hadiths, and have a distinctly Wahhabi-influenced outlook. As a result, they are oblivious of the connections between some adat narratives and the works of popular Muslim writers such as al-Tabari or al-Tha'labi, and are highly sensitive to the presence of ritual elements in the religious life of the local Muslim communities which may be associated with Christianity, a problem they preach about in the mosques. On the one hand, such interventions are effective: many of my respondents mentioned how they used to engage in rituals performed on Christian holidays but no longer did because it was "not one of our holidays". On the other hand, many local Muslims continue to seek help from priests and Christians as well as hodzhas. 


\subsubsection{Syncretism Resulting from Fear and Fascination with the Alien Numinosum: Visiting the Holy Sites of the Other Religion}

Muslims and Christians in the Rhodopes often believe that the only antidote to the harm caused by demons of another religion is available within that religion. Accordingly, they seek help from dzhindzhiya hodzhas or priests, but in doing so they never set out to learn more about the other religion. In such cases, the Muslims and the Christians are equally indifferent to the actual content of the prayer written down for them by a priest, or the amulet (amaliyka) received from a hodzha. Still, the practice involves a certain cathartic effect accompanied by a sense of fear and fascination with the alien sphere of the sacred. In this sense such experiences, though not motivated by an interest in the other religion, do not rule out the numinous experience.

However, we should not draw far-fetched conclusions from this fact. When discussing their motives for visiting a holy site belonging to a different religion, the respondents insist their belief in the religious and magical effectiveness of the local practices (such as sleeping in the church of St. George on May 5, offering a lamb in front of the eye can of St. George, washing one's face in water from the church's healing spring, lighting candles or leaving votive gifts in front of icons). When performed by Muslims, such rituals are not aimed at participating in Christian cult practices but simply reproducing certain gestures performed by Christians, believed to be effective in removing a medical condition. The Muslims are not unanimous about which of those gestures in a Christian holy place are permissible to Muslims, and which cross the boundary into idolatry; it seems that this is largely a matter of personal religious sensitivity.

Unquestionably, incubating in churches is seen as the most important practice, and the main reason pilgrims come to Hadzhidimovo. The other gestures are regarded as being of secondary importance and are performed "just in case" in a sort of uneasy compromise with their own religion. Those Muslims who light candles mostly do it in front of icons depicting saints mentioned in the Qur'an (in practical terms this means Jesus and Mary). All my respondents agreed that participating in Christian liturgy would be an act of transgression, and they leave the church before the liturgy begins.

Incubation as a healing practice in alien places of religious cult could be described as an instance of 'deep' syncretism only in those cases were the practice is liminal, which is not the case. This is clear from the fact that Muslims take pains to respect the boundaries of their distinct religious identity, which means the practice cannot be considered as syncretic. At the same time, the mere act of wearing an amulet containing a prayer of a different religion or the presence in one of its holy places are undoubtably cathartic experiences, and the belief in the resulting cleansing from physical and psychological ailments is connected with a numinous experience.

Ibelieve that the presence of Muslims and Christians in the same holy place should not be interpreted unequivocally in terms of what Hayden refers to as "antagonistic 
tolerance" 496 (2002, 2013a, Hayden, Walker 2013). This is only one possible scenario of contact between religions. However, I believe that Hayden's idea of viewing holy places as "indicators of political dominance, or challenges to it" (Hayden, Walker 2013, p. 413) is a very valuable insight which should inform future research in the area as it promises to provide social researchers with a better understanding of the attitudes of the religious elites administering a holy place with regard to members of another religion, and to see whether the attitudes of common believers are compatible with them (which may well not be the case). In the same way, differences of opinion are possible within the religious elite. For instance, most hodzhas or priests may refuse to provide healing services, but there are exceptions, a fact which is quickly noticed and used for propaganda purposes by their own religious group: people in Orthodox monasteries may boast that "even the hodzha has recently come here to seek healing" and vice versa. Orthodox clergy sometimes try to pressure Muslims into converting by refusing to perform healing practices on non-Christians. When this strategy fails, they offer compromise solutions (for instance, where a priest refuses to say prayers over a Muslim he may recommend leaving votive gift under an icon or wearing a prayer as a talisman).

It appears that some of the healing practices proposed by priests and hodzhas are analogues: Christian written prayers are similar to the Muslim amaliykas. Both are worn around the neck, and bring healing through direct contact with the sufferer. It remains an open question whether this similarity is a matter of coincidence or design (with both sides unwilling to lose their "custom" to the rival religious group), but rivalry undoubtedly triggers certain mimetic tendencies in both groups. On the one hand, the Muslim and Christian elites want to prevent their believers from seeking help from the other religion, on the other hand they derive satisfaction from being able to help a member of the other group as every success boosts the status of their religion and, in the case of Orthodox Christianity, the sanctity of the place in which miraculous healing is produced.

From the perspective of ordinary believers, seeking healing in the other religion has the double attraction of effectiveness and mystery. Because they are more incomprehensible than one's own traditions, alien practices are paradoxically closer to the awe-inspiring numinous experience which transcends conceptual understanding.

496 Hayden's thesis would seem far more warranted and applicable to my findings concerning religious syncretism in mixed Christian-Muslim communities if the model were based on "agonistic" rather than "antagonistic" tolerance, as originally coined by Hayden (see Chapter 5). 


\subsubsection{Syncretism as a Symptom of Komshuluk}

The same gesture may be performed because it is considered as an effective healing practice or because it fosters better relations with one's neighbours of a different religion. A good case in point is a Muslim woman who lights a candle for the deceased daughter of her Christian friends, a traditional Christian practice she performs during the wake in their home to show sympathy and solidarity. Her gesture is not religious but rather motivated by the ethics of good relations. The everyday experience of living side by side seems to play an important part in understanding religious syncretism between coexisting religious groups. When the declarative level ("we live like brothers") differs from the actual feelings felt for members of the other religion ("we fear them"), the "syncretic behaviors" occurring in the two groups must be examined with a pinch of salt. It is reasonable to suppose that shallow syncretism may serve the purpose of maintaining good relations, similar to other gestures based on the reciprocity rule (such as sharing festive foods, practical assistance, attending weddings and funerals, bringing gifts to new mothers).

At the same time, by engaging in such gestures to ensure peaceful relations Muslims and Christians get a chance to observe the religious rituals of the other group. Not infrequently this involves a measure of cognitive dissonance, which both groups deal with by means of narratives, which in their different ways reaffirm belief in the truth of their own religion and discredit the religion of the neighbours.

To return to Robert Hayden's concept of antagonistic tolerance, I wish to add that Muslims and Christians in the Rhodopes regard each other in terms which are not so much antagonistic as ambivalent. On the one hand, they seem to imagine the idea of tolerance along the lines of Mill's model, on the other hand they mistrust each other and discuss the memory of past conflicts and mutual injury. Although their fears about the threats to future peaceful coexistence are mainly aimed at politicians, they find it plausible that in a different political situation there neighbours might be capable of threatening their religious autonomy and their very existence. Based on the relationship of reciprocity, the idea of komshuluk confirms that religious tolerance in the region is not so much a given as a task requiring continued commitment.

\subsubsection{Syncretism as a Proselytizing Strategy}

Currently there are no significant groups in the research area to outwardly embrace the practices and beliefs of the other group in order to proselytize for their own. I only met one respondent with this approach, referred to in the book as "the syncretistist of Vodino" in the interest of preserving his anonymity. The syncretistist made conscious use of shallow syncretism as a method of winning the hearts of Muslims as part of his personal missionary activity. His motivation for seeking to convert his Muslim neighbours was the belief that salvation was not possible outside of Christianity. His 
efforts failed, but not before making his Muslim neighbours hopeful of his imminent conversion to Islam.

The syncretist's practice of studying the Bible and the Qur'an in parallel led to a selective form of religious belief: although he interpreted the Qur'an through the lens of the Bible (which he believes to be a superior source of revelation), he recognized as the most central to Christianity those elements which are not questioned by the Qur'an.

Although his case is unique and exceptional, it should not be dismissed as irrelevant, as the syncretist attracts considerable interest in the local community. $\mathrm{He}$ is perceived as a reliable source of advice and prayer support in difficult situations. In his own opinion, he acts as a kind of theological middleman for the (few) Muslim converts to Christianity in the area: he knows elements of the two religions which bring them closer together, making the experience of conversion easier.

\section{2 “Deep” Syncretism}

It seems warranted to say the 'deep' religious syncretism (in the sense of a synthesis of Orthodox Christianity and Islam) only occurs among Christians. This kind of syncretism finds expression in beliefs relating to the kurban as practised by Christians. Christians often describe the kurban as a necessary precondition for health in this world and salvation in the next. Blood sacrifice as practised by Balkan Slavs predates Islam and Christianity in this area, however its specific interpretations (expressed symbolically and etiologically) suggests deep parallels with the Muslim kurban, although Judaic influence cannot be ruled out in the rich body of beliefs related to the kurban (Badalanova 2008a, Lozanova 2008). Nonetheless, I suppose that the theologeme of Abraham's sacrifice, which plays an important part in Christian narratives and religious symbolism, was boosted by, or perhaps even introduced via, Ottoman religious culture, i.e. "Adat Islam”, which is closer to the Judaic tradition than modern "Salafi Islam". Because of this influence, I describe the religion of my Christian respondents as "Adat Orthodox Christianity". To me, this influence explains why blood sacrifice and sharing a sacrificial meal is more important to Christians in the Western Rhodopes than the Eucharist, which makes present Christianity's foundational event (Christ's blood sacrifice) in a bloodless form. Additional support for this conjecture comes in the great popularity of so-called "vowed kurbans". When they explain the need to make such sacrifice, Christians explain that in order to be sure of a saint's continued assistance after saving a person from disaster or serious illness one must continue to make the kurban every year until the end of one's life to give "blood for blood". This kind of syncretism has profound implications for the Orthodox Christian religious experience, a problem which calls for further interdisciplinary research.

It should be added that Christian respondents have a limited knowledge of Islam. They tell no narratives about Islam as such, preferring to share observations about 
the religious life of Bulgarian-speaking Muslims. Among themselves they refer to Bulgarian-speaking Muslim neighbours as "people turned Turk": people who left Christianity but have never become fully Muslim or Turkish. They list examples of their neighbours' supposed religious or cultural incompetence: they are not Turks because they cannot speak Turkish (“They don't have enough Turkish to buy a loaf of bread"), and are not recognized as fellow Turks in Turkey. In undermining the Islamic orthodoxy of the Bulgarian-speaking Muslims or describing them as cryptoChristians, such comments also shore up the respondents' belief in the validity of their own Christian worldview. The Bulgarian-speaking Muslims are perceived as a group secretly hankering after its Christian roots: apparently, they keep Christian items, such as Bibles or icons, hidden in their homes, and practice the same rituals. Christians perceive Muslim rituals in terms of equivalents or counterparts to Christianity; for instance, circumcision is seen as the Muslim equivalent of baptism. At the same time, they portray this ritual is the most characteristic distinguishing feature separating Muslims and Christians, a telling comment in the context of the low standards of religious knowledge among the Christians.

As they shape their respective religious lives, each group sees its own reflection in the eyes of the other. Hence, they often regard the identity-building function of baptism or circumcision as more important than its religious symbolism: the symbolic meaning of baptism or circumcision may be obscure as long as it is clear that the ritual makes one a Christian or a Muslim.

Paradoxically, it is the Orthodox Christians (who believe that their neighbours had been until recently crypto-Christians) who seem to be the most heavily influenced by Islam, even though this kind of influence is often denied in Bulgarian society, starting with school textbooks and ending with popular opinion. The period of Ottoman rule in Bulgaria is popularly believed to have been a "dark age" blamed for Bulgaria's arrested economic and cultural development (Szwat-Gyłybowa, Drzewiecka et al., 2011), but at the same time there is an insistence that this historical experience left no lasting mark on Bulgarian identity.

Consequently, Bulgaria finds itself in the paradoxical position where Ottoman influence is rejected as a constitutive element of Bulgarian identity not only by Christians, but also by Bulgarian-speaking Muslims, particularly by their religious elite. My research shows that in embracing "Salafi Islam”, the young Muslim religious elite has discarded many beliefs and practices which they consider to be adulterations and "additions" introduced under Ottoman rule. As a result, Islam in the Western Rhodopes is losing its pluralistic nature and local colour (Lubanska 2014).

By dismissing and rejecting past Ottoman influence as incompatible with their own religious or national tradition, both religious groups become alienated (Lubanska 2014), losing a crucial quality of coexistence described by Michael Herzfeld as "cultural intimacy" (Herzfeld 2005). Despite the temporary setbacks and breakdowns of good relations between neighbours, this cultural intimacy help them navigate parallel meanings and values focused on tolerance and balancing between "embracing the 
Other” and merely “enduring Him” (cf. Hayden, Walker 2013, p. 400). Much depends on the power relations between the groups and the current geopolitical situation (Hayden 2002, 2013, Hayden, Walker 2013). This is why it is my heartfelt wish for all my friends from the Rhodope Mountains that good relations with neighbours from the 44 houses around them will continue, and the camels will always diligently transport the bodies of the saved to the "correct" cemetery. 